\title{
Pesticide fate and behaviour in the UK Chalk aquifer, and implications for groundwater quality
}

\author{
P.J. Chilton ${ }^{1}$, M.E. Stuart ${ }^{1}$, D.C. Gooddy ${ }^{1}$, R.J. Williams ${ }^{2}$ \& A.C. Johnson ${ }^{2}$ \\ ${ }^{1}$ British Geological Survey, Wallingford OX10 8BB, UK (e-mail: J.chilton@bgs.ac.uk) \\ ${ }^{2}$ Centre for Ecology and Hydrology, Wallingford OX10 8BB, UK
}

\begin{abstract}
Field and laboratory studies have been used to assess the main factors that determine the fate and behaviour of agricultural herbicides in the Chalk aquifer of southern England. Field studies using isoproturon, chlortoluron and atrazine showed that leaching of pesticides from normal agricultural usage produces concentrations in Chalk groundwater of $0.01-1 \mu \mathrm{g} \mathrm{l-1}$ for most compounds, which are comparable with the current EU drinking water standard of 0.1 $\mu \mathrm{g} 1-1$. Where significantly higher concentrations are found in groundwater (up to three or four orders of magnitude higher), these are associated with localized 'point' usage or disposal, often combined with more rapid preferential transport pathways to the water table. Studies of the degradation of isoproturon, mecoprop and atrazine showed that these compounds are significantly more persistent in the Chalk than in soils, with half-lives measured in hundreds rather than tens of days. The observed order of magnitude variation in isoproturon half-lives spatially and with time makes the choice of values for predictive modelling problematic. The implications of the results for the quality at groundwater supply sources are discussed and compared with the situation for nitrate, and uncertainties in knowledge, and therefore the requirements for further work on both transport pathways and pesticide persistence, are reviewed.
\end{abstract}

Key Words: Chalk $\bullet$ groundwater sampling $\bullet$ unsaturated zone $\bullet$ saturated zone $\bullet$ isoproturon $\bullet$ chlortoluron $\bullet$ atrazine $\bullet$ degradation $\bullet$ persistence

\section{Introduction}

Advances in understanding of the processes responsible for the widespread increase in nitrate concentrations in groundwater led naturally to consideration of the risk to water supplies from pesticides. If nitrate could be leached from agricultural land, it seemed likely that, with intensification of pesticide usage, some of the more mobile compounds could also be leached to the underlying groundwater. However, research into pesticide fate and behaviour in the subsurface was initially hampered (Foster et al. 1991) by the technical sophistication and high cost needed to achieve the analytical detection limits required in relation to the EC Drinking Water Directive maximum allowable concentration of $0.1 \mu \mathrm{g} 1-1$. As sampling programmes have been developed and analytical methods have been refined, anincreasing number of pesticides have been detected in groundwaters of the UK (Walls et al. 1996), Europe (Leistra \& Boesten 1989; Spliid \& Køppen 1998) and North America (Barbash \& Resek 1996; Kolpin et al. 1996). These findings stimulated interest in research into the mechanisms by which pesticide residues could move from the land surface through the soil and the unsaturated zone to the water table, and the environmental conditions that would promote such movement. Research in this field remains a demanding and expensive task, because of the wide range of pesticides in common use, the low concentrations that need to be studied and the ensuing care required during sampling, and the continued high analytical costs.

Pesticide transport from the soil surface to groundwater is controlled by a number of processes: photodegradation, plant uptake, sorption to solid and possibly colloidal phases, 
dissolved phase migration, and subsurface chemical and microbially mediated degradation. Most existing data on pesticide attenuation processes come from studies on soils, and there are few such data for aquifers. It is not easy to evaluate how active such processes are below the top few metres or to provide the necessary basis for risk assessments of groundwater pollution by pesticides or predictive modelling of pesticide concentrations in groundwater. The principal aquifers providing public water supplies in the UK are consolidated sedimentary formations, which have the potential to permit transport of pesticides through both the matrix and fractures. Matrix flow would allow time for attenuation processes to operate, whereas preferential flow via fractures could allow very rapid transport of unattenuated pesticide residues to the water table. To assess the risk to such aquifers, especially where intensive agricultural land overlies the recharge areas of potable water supplies, both of these possible routes for contaminant transport need to be characterized.

The present paper summarizes and puts into context the findings of a study of pesticides in the Chalk aquifer of southern England, which was designed to examine and quantify the processes that control pesticide fate and behaviour. Within this broad objective, the specific aims of the study were: (1) to determine pesticide residues in the soil and the unsaturated and saturated zones of the Chalk; (2) to establish the importance of different recharge routes in the aquifer and their significance for pesticide transport; (3) to measure the potential for degradation and adsorption in the soil and the Chalk.

Specific aspects of the study dealing mainly with pesticide occurrence (Gooddy et al. 2001), degradation (Johnson et al. 1998, 2000) and transport (Besien et al. 2000; Johnson et al. 2001; Haria et al. 2003) have already been published, in addition to the final project report (Chilton et al. 2002). Here we bring together and summarize the results of the fate and transport work, discuss the implications for groundwater quality in the Chalk, and identify the most important remaining uncertainties that limit the confidence of drawing these implications, highlighting where further work is needed to improve the assessment of the risk of pollution of groundwater by pesticides.

One of the environmental objectives of the Water Framework Directive is that groundwater bodies should have good chemical status or that measures should be taken to achieve this. Status will be assessed against quality standards in a new Groundwater Directive, which is still being developed. This research will contribute to understanding the anticipated baseline conditions in the Chalk aquifer and consequently whether good status could be jeopardized by agricultural pesticides.

\section{Selection of study compounds and field sites}

At the start of the study in 1990 it was decided to focus on atrazine, isoproturon and mecoprop, as these compounds were both widely used in the UK (Ministry of Agriculture, Fisheries and Food 1991) and also had begun to be detected in groundwater (Lees \& McVeigh 1988). Subsequent groundwater monitoring for pesticides during 1992 and 1993 by the National Rivers Authority (1995) showed that these compounds continued to be amongst the most frequently detected pesticides. Atrazine remains the most commonly observed pesticide in UK groundwaters, but detections have decreased markedly since its withdrawal for non-crop use in 1992 (Environment Agency 2001).

Five field sites were selected for study (Table 1), which met the following criteria: (1) on the Chalk outcrop with the water table expected at a depth of less than $10 \mathrm{~m}$, giving high vulnerability to pollution and allowing easy sampling; (2) regular use of isoproturon or atrazine; (3) good records of cropping and fertilizer use going back at least 5 years. A condition of the site owners' participation was that precise locations would not be used in 
reporting the results of the study, so only the general distribution of the sites on the Chalk outcrop is shown in Figure 1.

\section{Methods of study}

The study employed a broad range of field and laboratory techniques, some of which had been modified or developed specifically (Table 2).

\section{Unsaturated zone sampling}

A summary of unsaturated zone sampling methods used is shown in Table 3. Boreholes were constructed by the dry percussion method with continuous, undisturbed cores from the Chalk unsaturated zone obtained within a PVC liner. These were capped and taped securely and stored at $20^{\circ} \mathrm{C}$ until processed (Chilton et al. 1993; Gooddy et al. 2001). Sampling followed two approaches. The first comprised high-speed centrifugation of crushed core material to extract porewater (Kinniburgh \& Miles 1983). In the initial part of the study, $250 \mathrm{ml}$ samples were required for determination of pesticides, and the traditional U100 tubes were replaced by a larger U150 type, so that adequate volumes of core could be retrieved (Table 3 ). The later use of enzyme-linked immunosorbent assay (ELISA) had the great advantage of requiring only $2 \mathrm{ml}$ of porewater. Samples were also taken for dissolved organic carbon, chloride and nitrate determination. The second approach was to extract pesticide residues from the solid chalk core with methanol, and methods were developed for isoproturon, chlortoluron and atrazine determination, as shown in Table 4.

\section{Saturated zone sampling}

In the initial phase of fieldwork, one permanent observation borehole was constructed at each of the four Hampshire sites (Table 1 and Fig. 1). Boreholes were completed c. $3 \mathrm{~m}$ below the rest water level with sufficient slotted PVC casing to accommodate the seasonal fluctuations in water level. These boreholes were purged and sampled once or twice per month, immediately after measurement of groundwater level. At site WON, further sampling boreholes were constructed ( Fig. 2).

To focus sampling more closely on the direct and more rapid infiltration through fractures in the Chalk, a hanging multi-level sampler and a programmable automatic pumped sampler were developed and installed in boreholes at site WON (Gooddy et al. 2001). The first, accompanied by a pressure transducer to measure groundwater levels, collected a series of discrete water samples during periods of rapid water table rise, and the second could be programmed to take pumped groundwater samples at frequent intervals immediately following pesticide application (Johnson et al. 2001). Sampling intervals ranged from daily to once every $30 \mathrm{~min}$ following pesticide application. Because so many samples were collected, rainfall and water-level data were used to select for analysis samples from times during possible recharge events when elevated concentrations in very shallow groundwater might be anticipated.

\section{Unsaturated zone hydrology}

A comprehensive array of soil and unsaturated zone hydrological instrumentation was installed at site WON (Chilton et al. 2002; Haria et al. 2003). Rainfall was measured by a recording tipping-bucket rain gauge. Changes in soil water content were recorded by capacitance probes set at depths of 0.1 and $0.3 \mathrm{~m}$. Soil water potentials were measured by eight pressure transducer tensiometers (PTTs). Data loggers recorded hourly measurements 
from the rain gauge, capacitance probes and PTTs throughout the field season. Weekly measurements of soil water content were obtained from neutron probes installed to $3 \mathrm{~m}$ depth.

Pesticide sorption and degradation

Sorption and degradation were addressed in a series of laboratory studies summarized in Table 5.

\section{Results and discussion}

\section{Pesticide residues in the unsaturated zone}

In the earliest coring undertaken in 1991 and 1992 at sites LEC, WON and AWC (Fig. 1), where the herbicide isoproturon had been used in the cultivation of winter cereals, there were very few positive determinations above detection limits. In contrast, beneath maize cultivation at sites CPN and ASM, positive detections of atrazine were generally observed down to $5 \mathrm{~m}$ (Table 6). Porewaters from the CPN cores were characterized by particularly high nitrate concentrations (20-50 mg N 1-1), possibly reflecting the high nitrogen applications to maize. This suggested that the sampled porewaters are representative of local infiltration that had passed through the soil zone, and would, therefore, have picked up residues of atrazine if they had existed in substantial quantities. Similar drilling investigations, including some at the same CPN site, undertaken by WRc and reported by Clark et al. (1995) also detected only low concentrations of pesticides in the unsaturated zone (Table 6).

The results of further drilling undertaken in 1996 and 1997 at site WON confirm the generally low concentrations. The results of analysis by ELISA of porewaters from boreholes W7, W9 and W10 (Fig. 2) indicated very low isoproturon concentrations, at or close to the detection limit of $0.01 \mu \mathrm{g} \mathrm{l}-1$, with no concentrations above $0.05 \mu \mathrm{g} \mathrm{l}-1$ (Gooddy et al. 2001). Concentrations of both isoproturon and and chlortoluron, obtained by methanol extraction from the Chalk core material from five shallow boreholes at site WON, were also consistently low, with few observations below the soil zone greater than the detection limit of $0.2 \mu \mathrm{g} \mathrm{kg}-1$ (Gooddy et al. 2001).

Comparison of pesticide concentrations derived by solid and liquid extraction can provide an indication of the degree to which downward transport of pesticide is retarded by sorption. Concentrations obtained by extraction from the chalk matrix reflect a combination of any immobile pesticide sorbed onto either the solid chalk or organic matter contained in it, and the dissolved residues. The measured porewater concentrations represent strictly the dissolved phase in all but the most difficult to extract water. Thus, if concentrations estimated from solid extractions were many times greater than those measured in porewaters, this would imply that significant pesticide residues were bound permanently or temporarily in the chalk matrix. From the results presented in Table 6, total and porewater concentrations were reasonably equivalent, bearing in mind that the solid and porewater samples were not from precisely the same points in the profile. This suggests that sorption is likely to be a much less important attenuation mechanism in the Chalk aquifer than in the soil, reflecting the former's much lower organic matter content (Foster et al. 1991).

There are differences between boreholes that are likely to reflect local heterogeneity in infiltration, attenuation and transport properties of the chalk and soil across the field, even though the distributions of chloride, nitrate and dissolved organic carbon are much more homogeneous (Gooddy et al. 2001). There remains an overall discrepancy in concentrations between the ELISA-analysed porewaters and the methanol-extracted solid chalk. These differences are much greater than those found between solid and porewater results in the 1991 work (Table 6), and it is not clear whether this difference is between extraction or analytical methods. Whereas the earlier interpretation of the solid extraction results suggested that the amount of pesticide sorbed onto the aquifer matrix was likely to be negligible, the later 
methanol extraction results may appear to contradict this. One possibility is that pesticides are also transported sorbed onto organic colloidal particles, which the solid extractions would detect and ELISA would not. This possibility was suggested by Foster et al. (1991) and its role in pesticide transport in clay soils was investigated by Worrall et al. (1999) using shallow lysimeters. If this were occurring the methanol extractions would be measuring pesticides sorbed onto colloidal particles of material with much greater adsorption potential than the chalk matrix itself, and whose downward progress has been restricted by the narrow apertures or constrictions of microfractures. Intermittent and rather heterogeneous colloidal transport of pesticides would be consistent with and utilize the additional storage sites in the irregularities of chalk fracture surfaces described by Price et al. (2000). Colloids could also be intermittently remobilized by the wetting up around the chalk fracture contact points postulated by Haria et al. (2003).

\section{Pesticide residues in the saturated zone}

The results of the regular sampling of the initial four observation boreholes are summarized in Table 7. At site LEC, practically no positive detections of isoproturon were observed, reflecting the significant elapse of time since isoproturon was used, and sampling was therefore curtailed. At sites AWC and ASM, isoproturon and atrazine respectively were consistently detected at low concentrations. Groundwater levels and nitrate concentrations at both sites responded to winter recharge, but pesticide concentrations remained low ( Fig. 3). Similarly low concentrations ( $1 \mu \mathrm{g} 1-1$ or less) of these pesticide compounds, together with simazine and chlortoluron, were detected in groundwater samples from private boreholes and observation boreholes in the Chalk of the Granta catchment in eastern England (Clark et al. 1991).

The establishment of several boreholes on the sloping field at site WON allowed groundwater samples to be taken at a range of water table depths (Table 7). In the early years of sampling from borehole WON4, most observed isoproturon concentrations were below the $0.05 \mu \mathrm{g} \mathrm{l}-1$ detection limit, reflecting the long period since the last application ( Fig. 4). Later in the study, chlortoluron, which had not previously been used agriculturally at site WON, was applied in October 1996 over limited parts of the field around the sampled boreholes. Detections of this compound, whose properties are rather similar to those of isoproturon, were comparable, being most frequently observed at the lower part of the field in boreholes W5 and W15, less so at W6 and rarely in W7, where the water table was much deeper (Fig. 2). Table 7 also shows that the percentage of positive detections increased in the later sampling, as analytical capability improved and lower detection limits were achieved.

Comparison of unsaturated zone porewater nitrate concentrations beneath the soil (15-30 mg $\mathrm{N} \mathrm{1-1)} \mathrm{with} \mathrm{those} \mathrm{measured} \mathrm{in} \mathrm{samples} \mathrm{from} \mathrm{the} \mathrm{automatic} \mathrm{sampler} \mathrm{(8-16} \mathrm{mg} \mathrm{N} \mathrm{1-1)} \mathrm{indicated}$ a possible dilution at the water table of about two. Thus possibly only half of the water reaching the sampled boreholes would have originated relatively recently from nearby within the field. The hanging sampler developed to target the most recent recharge more closely was first deployed in borehole WON4 to observe the response to the application of isoproturon in December 1995. Concentrations of $0.1-0.15 \mu \mathrm{g} \mathrm{l}-1$ prior to application increased to $0.2-0.3$ $\mu \mathrm{g} 1-1$ immediately following application, associated with a rise in groundwater level of more than $2 \mathrm{~m}$ in response to recharge in a 6 week period ( Fig. 5; Gooddy et al. 2001). This suggests the transport of pesticide, albeit of small amounts, in rapidly infiltrating water in the Chalk fractures. Concentrations subsequently declined to around $0.1 \mu \mathrm{g} 1-1$. Over the next winter, following the application of chlortoluron, no significant rise in concentration was observed in the multi-level sampler compared with routine pumped samples, with concentrations averaging $0.12 \mu \mathrm{g} \mathrm{l}-1$. This suggested that the rise in concentration may have been due to the rise in groundwater level, and this was corroborated by results from the automatic sampler. 
The automatic sampler was operated in borehole WON5 over three winter seasons. Following a single isoproturon application in December 1995 significant peaks in concentration were observed annually during each recharge season ( Fig. 6), but declining from year to year, reflecting the lesser amounts of residue available for mobilization. It is postulated that the source is probably pesticide held up at the soil-chalk interface and being mobilized seasonally through preferential flow events (Johnson et al. 2001). Following the 1996 chlortoluron application, background concentrations from the automatic sampler rose from 0.2 to $0.4 \mu \mathrm{g} 1-$ 1 , with peaks of 0.8 and $0.6 \mu \mathrm{g} \mathrm{l-1} \mathrm{(Gooddy} \mathrm{et} \mathrm{al.} \mathrm{2001).} \mathrm{Chlortoluron} \mathrm{concentrations} \mathrm{in}$ 1997-1998 closely matched those of isoproturon in Figure 6 in being lower overall than in the previous year. Concentrations obtained by the automatic sampler were up to double those detected in samples from borehole WON4, either by routine pumping or from the hanging sampler (Table 7). This sampling approach may have been successful in capturing a greater proportion of new recharge water with higher pesticide concentrations from the vicinity of the borehole.

\section{Unsaturated zone water movement}

Measurements of chalk water potentials at site WON using pressure transducer tensiometers showed a different response to rainfall events over the field (Haria et al. 2003). The potentials at the lower area showed the gradual wetting up of the shallow profile in response to small amounts of rain. A larger rainfall event produced a rapid response at very shallow depths, indicating the potential for rapid movement of water, and hence pesticide, through the top horizon of the soil profile. The response was attenuated at greater depths, indicating that water movement through this zone occurs at a reduced rate. This rate was slower than during preferential flow, which would be expected to give an instantaneous or at least very rapid response, but faster than could be explained by matrix flow alone. In contrast, for the same rainfall event only matrix flow through the unsaturated zone was observed at the higher part of the field, where the water table is $18-20 \mathrm{~m}$ below ground level (Haria et al. 2003). This suggested different flow pathways for this event between the higher site closest to the interfluve and that closest to the dry valley bottom. In practice, there is probably a spectrum of discontinuities in the Chalk, from matrix pores through macropores and small fractures, to significant fissures, and therefore a range of possible flow and transport pathways.

It has been suggested that matric potentials of more than $5 \mathrm{kPa}$ indicate conditions favouring the onset of preferential flow mechanisms (Wellings 1984). Table 8 summarizes the periods over two winters where such potentials occurred at $3 \mathrm{~m}$ depth. Whereas favourable conditions occurred for several weeks in 1995-1996, there were only two limited periods the following year. Wellings (1984) observed fracture flow in the Chalk unsaturated zone only once during a 5 year period, and the conditions for fracture flow are clearly not frequently encountered.

The difference in behaviour at the lower and upper parts of the field might be thought to result simply from the greater likelihood of connected flow pathways persisting to the water table at 3-5 m depths than at 18-20 m (Fig. 2). However, for one rainfall event studied in detail by Haria et al. (2003), matric potentials at $3 \mathrm{~m}$ depth at the upper part of the site did not exceed $17 \mathrm{kPa}$. This is well below the threshold of $-5 \mathrm{kPa}$ suggested by Wellings (1984), implying that deeper fractures would not in fact become active flow conduits at the upper part of the site, although they did for the same rainfall event at the lower part. Even if fracture flow were initiated at shallow depth at the upper part of the site, it would be dissipated into the chalk matrix within the uppermost few metres.

In discussing the implications of this finding, Haria et al. (2003) suggested that the capillary fringe may play a role by keeping the shallower unsaturated zone profile more adequately supplied with water. This could help to fill the intermediate storage sites provided by 
irregularities in the fractures (Price et al. 2000) or at contact points between the fracture walls (Haria et al. 2003), so that less water is required to wet the profile before preferential flow occurs following infiltration after a rainfall event. Infiltration from the soil after heavy rain might, therefore, initiate preferential flow more easily where the water table is shallower. The shorter fracture flow pathways through the thinner unsaturated zone may present a greater possibility of carrying this more rapid but rarely occurring flow to the water table.

\section{Pesticide retardation}

Samples of chalk taken for the batch sorption experiments all had total organic carbon concentrations below the detection limit of $0.1 \%$ and very low pesticide Kd values, ranging from less than 0.01 to $0.021 \mathrm{~kg}-1$ (Besien et al. 2000). These results are in agreement with the low pesticide concentrations obtained by solid chalk extraction referred to above (Table 5), and they provide further support to the suggestion of Foster et al. (1991) that the UK's sandstone, chalk and limestone aquifers contain little material with which to attenuate pesticides by adsorption.

Evidence about retardation also comes from the behaviour of the applied pesticide relative to bromide in column leaching experiments. Retardation factors were calculated from the respective pore volumes required to leach $50 \%$ and the respective times to reach peak concentrations of bromide and pesticide (Besien et al. 2000). These ranged from 1.09 to 1.49 by the former and from 1.12 to 1.43 by the latter, and can be compared with a value of 1.08 calculated by the equation of Foster et al. (1991):

$$
R=1+\frac{K_{\mathrm{d}}(1-n) \rho_{\mathrm{s}}}{\theta}
$$

where $\mathrm{R}$ is the retardation factor and using a porosity (n) of 0.43 , chalk grain density ( $\{$ rho $\} \mathrm{s}$ ) of $2.7 \mathrm{~kg} \mathrm{l}-1$, volumetric water content (\{theta $\}$ ) of 0.4 and distribution coefficient $(\mathrm{Kd})$ of $0.021 \mathrm{~kg}-1$ obtained from the batch sorption experiments. This suggests that the simple batch sorption experiments might underestimate the retardation factor, compared with the column leaching experiments.

The bromide breakthrough curves could be accurately simulated using a simple convectiondispersion numerical model, although the more unusual shapes of the equivalent curves for isoproturon could not be simulated with the same model. Dye tracing studies undertaken on the columns confirmed that most of the flow was through the chalk matrix, but with significant small-scale variations in transport (Besien et al. 2000).

The above work would not have fully quantified retardation from applications at a site as pesticide retardation takes place predominantly in the soil, and this was not simulated in the experiments.

\section{Pesticide persistence}

Initial experiments confirmed that, for pesticide degradation to occur, subsurface microbial communities needed to have the solid matrix provided by a solid:liquid slurry, rather than being dispersed in a groundwater-only medium (Hughes et al. 1995), and demonstrated that isoproturon could be degraded in microcosms from a chalk site where isoproturon had never been used, as long as solid chalk was present. This agreed with other findings within the study (Chilton et al. 1993; Johnson et al. 1998), and it is suggested that bacteria in the groundwater require a surface for attachment, before multiplication and/or production of enzymes capable of degrading isoproturon can occur. Investigating pesticide behaviour in groundwater only (Cavalier et al. 1991) may not be a reliable guide to pesticide persistence in aquifers, and this was taken into account in the subsequent design of the microcosms. 
Testing of the potential of the soil at site WON to degrade isoproturon, atrazine and mecoprop showed that all three compounds could be readily degraded in the soil, with half-lives of 1582 days. Whereas isoproturon had been used previously on a number of occasions there was no record of atrazine or mecoprop use. Hughes et al. (1995) also found isoproturon degradation potential at a site where there was no recorded use, although there was a delay of some weeks before degradation began, which was attributed to 'a period of adjustment' by microbes, which had not previously been exposed. A similar lag had previously been observed in sandy aquifers (Heron \& Christensen 1992; Klint et al. 1993). This is also consistent with recently published results from Danish chalk aquifers, where lag times of at least 40 days were observed before measurable degradation occurred (Kristensen et al. 2001).

Degradation of isoproturon in microcosms containing groundwater and chalk from both the unsaturated and saturated zones was demonstrated. The most rapid degradation (half-life of 104 days) was observed for groundwater with sterile chalk, followed by the unsaturated zone (120-230 days) and saturated zone (250-300 days) (Johnson et al. 2000). Metabolites previously associated with soil degradation (Lehr et al. 1996) were observed in all the groundwater-chalk combinations except the sterile controls.

Table 9 summarizes the broad range of isoproturon degradation potential in microcosms using groundwater samples taken from the different boreholes at site WON since May 1995. These results demonstrate that the potential for degradation of isoproturon is both spatially and temporally variable, underlining the complexity of the subsurface ecosystem. It is interesting to note, in particular, that WON4 and WON5 gave such different results, despite being only $10 \mathrm{~m}$ apart.

Examination of the potential for isoproturon degradation at lower concentrations showed little evidence of degradation at $0.7 \mu \mathrm{g} \mathrm{l}-1$ over 350 days. This cannot, however, be accepted as a definitive answer to whether pesticides can be degraded at the concentrations actually observed in the field, because of the variability of groundwater samples in degrading $100 \mu \mathrm{g}$ 1-1 isoproturon, shown in Table 9.

\section{Degradation of other herbicides}

Initially, no degradation potential was observed for atrazine at site WON over a 200 day period, or for mecoprop over 150 days in chalk samples, despite the soil above being able to degrade these compounds. In subsequent experiments with samples of chalk groundwater from the other Hampshire sites, it was found that only 1-3\% of atrazine was converted to dealkylated metabolites following a 1 year incubation period, suggesting very slow degradation and half-lives measured in years (Johnson et al. 2003). The mecoprop results are in contrast to those from earlier work, where a potential was observed at all the study sites (Chilton et al. 1993). The difference in results may be a further reflection of spatial variability in degradation potential. The study also highlighted the effects of storage of groundwater samples before use in microcosms, as degradation potential was lost with time, and this could be a further reason for inconsistencies in experimental results.

\section{Implications for groundwater quality}

These findings have important implications with regard to the potential impact of agricultural herbicides on groundwater quality in the UK. These are discussed below, indicating both those aspects that can be considered to be known with some confidence and those that are more uncertain and require further work. 
The unsaturated zone sampling indicates that, beneath normal agricultural cropping and with pesticide applications at recommended rates, only very small amounts of pesticide are moving through the unsaturated zone matrix of the Chalk. Observed concentrations of both isoproturon and atrazine were rarely above $1 \mu \mathrm{g} \mathrm{l}-1$ and always less than $10 \mu \mathrm{g} 1-1$. These results are also consistent with those obtained by Clark et al. (1995) for mecoprop and trietazine in the Sherwood Sandstone aquifer (Table 6). Given that, from normal application rates of 1-3 kg ha-1, pesticide concentrations of several hundred to more than $1000 \mu \mathrm{g} \mathrm{l}-1$ could be present in the topsoil immediately after application, this is confirmation of the effectiveness of surface and soil processes of pesticide loss or dissipation. Very little pesticide remains and is available for transport, and the proportion leached beneath the soil zone is rarely even $1 \%$ of the amount applied. The results of the unsaturated zone sampling presented here suggest that less than this is moving slowly downwards through the chalk matrix. Sampling in the saturated zone in the present study has confirmed that very low concentrations of agricultural pesticides are reaching the water table by leaching from overlying agricultural land. Given the opportunities for dilution further down the saturated zone flow path, this must be considered a reassuring finding for the security of public water supplies, and other potential groundwater receptors, such as rivers, lakes and wetlands.

Although the present study has confirmed the earlier findings for the Chalk at nearby Bridgets Farm (Wellings 1984) that conditions promoting rapid unsaturated zone movement through fractures do not occur frequently, the quantification of the fracture flow proportion still remains uncertain. At Bridgets Farm it appeared that, on rare occasions, rainfall of very high intensity would exceed the infiltration capacity of the matrix, and fracture flow could result, irrespective of the prevailing matric potential. At this site $30 \%$ of the total lysimeter drainage was attributed to fracture flow (Wellings 1984), but this would not necessarily equate with preferential transport of solutes down to the water table. Sampling of pesticide concentrations during preferential flow events would be needed to be able to estimate the proportion of applied pesticides transported by this route.

Fracture flow originating at the soil is more likely to reach the water table directly where it is shallow, as such flow initiated near the surface may be dissipated into the matrix where the depth to the water table is greater. Fracture connectivity is much more likely to persist to a shallow than to a deep water table and the influence of the capillary fringe on transport routes may also be felt more strongly where the water table is close to the surface, as suggested by Haria et al. (2003). It could be argued that pesticide 'hot spots' in groundwater in the Chalk may occur only where the depth to water does not exceed, for example, $5 \mathrm{~m}$. This would represent only about $1 \%$ of the surface area of the Chalk outcrop in SE England (Lewis et al. 1993), again providing general reassurance about the overall impact on Chalk water supplies of conventional agricultural pesticide usage.

\section{Spatial and temporal variability of pesticide persistence}

The microcosm experiments have shown that there are bacterial communities present in the Chalk aquifer competent to degrade pesticides, and confirmed that breakdown occurs more slowly than in the soil. However, observed degradation rates were variable, and could not be predicted from either nutrient levels or the number of bacteria present (Johnson et al. 2003). Additionally, degradation potential was not evenly distributed spatially in the Chalk and groundwater and, moreover, appeared to be a somewhat transient quality. This is an important finding. Isoproturon degradation potential has been shown to be spatially variable in other studies, even in agricultural soils where the potential is relatively high. Walker et al. (2001) found a five-fold variation in degradation rate over a single field with nominally uniform soil characteristics, together with differences in degradation kinetics. In Denmark, Kristensen et al. (2001) also observed large variations in rate and extent of mineralization of mecoprop and isoproturon in a chalk aquifer, and Albrechtsen et al. (2001) reported substantial spatial variability in herbicide degradation in a range of shallow aquifers. Earlier work by Heron \& Christensen (1992) had noted different patterns and rates of mecoprop degradation for 
groundwater collected from boreholes only $2-10 \mathrm{~m}$ apart. None of these studies referred to the temporal variability found here, but the range of variation described must have important implications for extrapolating data from microcosms or single boreholes to larger aquifer units or geographical areas.

These findings illustrate how data collected from a single location on a single date could produce misleading interpretations about the potential for pesticide degradation. Although problematic for predictive modelling and pollution risk assessment, this should not be considered surprising, as the factors that determine degradation potential such as bacterial populations, availability of nutrients, moisture conditions and oxygen status are likely to vary spatially, and their distribution may often be controlled largely by the physical properties. Even without major fracture flow, the small-scale spatial variability in soil, subsoil, slopes and drainage are likely to produce effects such as local subsurface 'ponding' of flow (Foster et al. 1991) and consequent differences in infiltration of water, bacteria, nutrients, colloids and pesticide residues to the subsurface.

Hence, the question posed by Johnson et al. (2000), 'will herbicides be degraded in situ in fractured aquifers?' remains a crucial one. Field studies of the potential for a microbial contribution to denitrification in the major UK aquifers (Lawrence \& Foster 1986; Kinniburgh et al. 1999) suggested that denitrification would be largely restricted to the fractures, and the greatest activity was likely to take place on the fracture walls. This was partly because the very small pore size (about $1 \mu \mathrm{m}$ ) would exclude most bacteria, but also because some of the requisite nutrients are likely to be more available along the fractures. Given the difficulty of representing such conditions in the laboratory, microcosms containing crushed chalk and groundwater used in the present study may be poorly representative of field conditions in either matrix or fracture environment.

This study has indicated, as expected from overall considerations of microbial populations and nutrient status, that degradation is slower in the underlying aquifer than in soils, and the results are believed to be the first such data reported for the UK Chalk. Questions remain as to whether the indigenous microflora would degrade isoproturon at $0.1 \mu \mathrm{g} 1-1$ and at field temperatures (c. $10^{\circ} \mathrm{C}$ ) in the same way as at the $100 \mu \mathrm{g} \mathrm{l}-1$ and 15 or $20^{\circ} \mathrm{C}$ used in the microcosms.

\section{Evolution of groundwater pesticide concentrations}

The situation for pesticides can be compared with that for nitrate, which has long been a major groundwater quality concern for the UK water industry. Leaching losses of nitrogen from agricultural land often reach 20-30\% of the applied fertilizer (Armstrong \& Burt 1993) and nitrate, once formed, is highly soluble, relatively stable in aerobic conditions and poorly sorbed. Resulting nitrate concentrations in the unsaturated zone matrix determined by porewater profiling (Foster et al. 1986) range up to 50-150 mg Nl-1 under common agricultural scenarios. Once in the unsaturated zone, little further attenuation of nitrate occurs. Given the slow downward movement through the Chalk matrix in the unsaturated zone of 1-2 m a-1 (Wellings 1984; Geake \& Foster 1989; Barraclough et al. 1994), large amounts of nitrate have been observed stored in the unsaturated zone, eventually to affect saturated zone groundwater quality. This mechanism has given rise to the 'time-bomb' scenario of the more emotive environmental commentators. Once in the unsaturated zone, this high-nitrate recharge water moves down to the saturated zone and to water supply sources, albeit with mixing and dilution on the way.

In contrast, the results of this study and that of Clark et al. (1995) indicate that there are no significant quantities of pesticide residues from agricultural applications lodged in the unsaturated zone. The 'time bomb' scenario does not apply in the same way for pesticides, and this is an important finding. Only low pesticide concentrations have been consistently observed at the water table, and there is no evidence of a cumulative rise in concentrations of 
specific compounds. Further dilution is likely within the saturated zone pathway to water supply sources and other receptors. It seems unlikely, therefore, that normal agricultural usage of pesticides in the UK will produce gradually rising concentrations of specific compounds in drinking water supplies. Several factors may help to explain this outcome.

- The processes of pesticide attenuation and dissipation in the soil are highly effective in reducing concentrations, leaving little available for leaching (this is required by the registration process).

- The combination of crop rotations and availability of more than one compound for the same weed control task mean that individual compounds are rarely used on the same field continuously from year to year, greatly lessening the opportunity for residue accumulation. Table 10 shows the number of compounds applied to the various crops in 11 successive years at one site. In contrast, most crops will receive nitrogen fertilizers each year.

- The widespread adoption of crop rotation practices also means that any specific compound is used on a relatively small proportion of agricultural land in a catchment or protection zone each year, again in contrast to nitrogen fertilizers.

- Although more vulnerable to leaching, the lighter and thinner soils that are common over aquifer outcrops may have less vigorous weed development, requiring lower pesticide applications than on thicker, heavier alluvial clay soils.

- Successive generations of new pesticide compounds and mixes are effective at lower application rates.

- The slow unsaturated zone transport through the matrix allows time for further degradation.

- More rapid, preferential flow in fractures appears to be a relatively uncommon occurrence at the study sites, although pesticide problems have been identified in areas of the Chalk where karst features are well developed (Worrall \& Besien 2005);

- Transport of pesticides directly to the water table may be restricted to areas where the water table is shallow. This was also suggested by Worrall \& Kolpin (2004).

\section{Comparison with point sources of pesticides}

The same considerations do not always hold for non-agricultural pesticide usage or pesticide disposal, both of which may result in point sources of pollution, with very different mechanisms and outcomes (Chilton et al. 2000). The heaviest non-agricultural usage of herbicides is for total weed control of paved areas, highways, railway lines, car parks and airfields. This poses a particular threat to groundwater because in many instances such areas are drained by soakaways, and pesticides may therefore bypass the soil and enter the subsurface with much less scope for attenuation. As an example, approval of atrazine for nonagricultural use was withdrawn in the UK in 1992, but it continued to be responsible for most pesticide exceedences in public supplies from groundwater for some years. Figure 7 demonstrates the continued persistence of atrazine in a public supply borehole abstracting from the Chalk aquifer close to a railway line (UK Water Industry Research 2003).

Incorrect or careless handling or disposal can also lead to point-source contamination. Elevated concentrations of a range of herbicides derived from a soakaway adjacent to a pesticide storage area on the Chalk of southern England were detected in porewaters beneath the site ( Fig. 8). These concentrations are three orders of magnitude higher than those in Table 5, and gave rise to troublesome concentrations at a major groundwater supply source 3 $\mathrm{km}$ downgradient (Chilton et al. 2000). 
Pesticides other than herbicides can also be responsible for point-source pollution. Diazinon, propetamphos and chlorfenvinphos, insecticides then used in sheep dip, were detected in shallow groundwater at up to $5 \mu \mathrm{g} 1-1$ downgradient of sheep dip installations (Blackmore \& Clark 1994). There is also evidence that pesticides are present in leachate from waste disposal sites. Liquid wastes from pesticide manufacturing were leached from a landfill site in the Jurassic limestone of eastern England, giving rise to contamination of the aquifer by a range of pesticides, including mecoprop (Sweeney et al. 1998). Concentrations of up to $30000 \mu \mathrm{g} 1-$ 1 were detected in the saturated zone in the immediate proximity to the site, but little was detected in the porewaters and it appeared that transport was mainly by the fissures of this heavily fractured limestone. Concentrations of up to $25 \mu \mathrm{g} 1-1$ in a public supply borehole 3 $\mathrm{km}$ away caused it to be withdrawn from supply.

Although these latter two examples are not from the Chalk, they serve to illustrate the differences between diffuse and point-source pollution scenarios, which are illustrated in Figure 9 to show the full spectrum of pesticide sources. Thus, diffuse pollution ranges from temperate monoculture applications such as atrazine in maize cultivation in the mid-west cornbelt states of the USA, where a very high proportion of the recharge would contain pesticide residues, and agricultural impacts are clearly observed (Barbash \& Resek 1996), to the rotational farming systems covered in the present study. Tropical agricultural uses, often with higher application rates and using irrigation, have been observed to result in higher concentrations of pesticides in groundwater (Chilton et al. 2000). Linear or multiple point sources include railways, highways and airfields, and point sources include the disposal examples quoted above, in which a small proportion of the catchment recharge carries high levels of pesticide residues. The impact of these pollution sources on groundwater quality depends on the local hydrogeological situation, especially the scope for dilution and retardation within the subsurface pathway.

\section{Conclusions}

The results of the study provide some of the first field evidence in the UK for the fate of agricultural herbicides in the Chalk aquifer. Sampling in the unsaturated zone at five sites in southern England has observed low concentrations of atrazine (generally $<3 \mu \mathrm{g} 1-1$ ) and almost negligible concentrations of isoproturon in both the saturated and unsaturated zones. It seems unlikely, therefore, that troublesome concentrations of pesticides derived from normal agricultural use would develop in Chalk groundwater if movement through the matrix were the only transport mechanism operating. Although more rapid transport from the soil to the Chalk water table via fractures can be envisaged, evidence from this and other studies suggests that it occurs infrequently. Even when fracture flow is encouraged or initiated, rapid transport of solutes to the water table may occur only where it is close to the ground surface, which is the case for a relatively small proportion of the Chalk outcrop.

It can be concluded on this evidence, therefore, that conventional applications of agricultural pesticides present only a limited threat to Chalk groundwater supplies. This cannot be said for point sources, whose initially very high concentrations at infiltration have been observed to produce concentrations in abstracted water from public supplies many times higher than those allowable in drinking water, even after dilution in the regional groundwater flow system. These findings contribute to understanding the anticipated baseline conditions in the Chalk aquifer and consequently whether Water Framework Directive 'good status' could be jeopardized by agricultural pesticides.

Bacteria capable of degrading pesticides are present in the Chalk aquifer, albeit in smaller populations than in the soil and not evenly distributed. Degradation of isoproturon is slower 
than in the soil, but still effective in breaking down the parent compound. Evidence for mecoprop degradation was inconsistent, and almost no potential was found for atrazine degradation in the present study. The observed spatial and temporal variability of isoproturon persistence provides an indication of the limitations of using data from a single location or time in predictions of pesticide fate and behaviour.

A number of important uncertainties remain in assessing the risk of pesticide pollution of groundwater. First, the fracture component of unsaturated zone flow has not been fully characterized or quantified, nor has it yet proved possible to sample this unsaturated zone flow component for pesticides while it is actually happening. Second, subsurface pesticide persistence has not been fully characterized at ambient temperatures and concentrations, and in relation to matrix and fracture pathways and their respective controls on the distribution of bacterial populations and nutrients. Finally, current UK monitoring of groundwater takes relatively little account of pesticide metabolites, although there is increasing evidence of their occurrence in groundwater.

\section{Acknowledgements}

The authors are grateful to their many colleagues and collaborators who have contributed to work described here. Funding for the research was provided initially by the UK National Rivers Authority (predecessor to the Environment Agency), and latterly by the Natural Environment Research Council. This paper is published by permission of the Executive Director of the British Geological Survey (NERC).

\section{References}

Albrechtsen, H.J., Mills, M.S., Aamand, J., Bjerg, P.L., Degradation of herbicides in shallow Danish aquifers: an integrated laboratory and field study. Pesticide Management Science, 57 2001. 341-350.

Armstrong, A.C., Burt, T.P., Nitrate losses from agricultural land. In: Burt, T.P., Heathwaite, A.L. \& Trudgill, S.T. (eds) Nitrate Processes, Patterns and Management., 1993. 239-267 Wiley, Chichester.

Barbash, J.E., Resek, E.H., Pesticides in Ground Water: Distribution, Trends and Governing Factors., 1996. Ann Arbor Press, Chelsea, MI.

Barraclough, D., Gardner, C.M.K., Wellings, S.R., Cooper, J.D., A tracer investigation into the importance of fissure flow in the unsaturated zone of the British Upper Chalk. Journal of Hydrology, 156 1994. 459-469.

Besien, T.J., Williams, R.J., Johnson, A.C., The transport and behaviour of isoproturon in unsaturated chalk cores. Journal of Contaminant Hydrology, 43 2000. 91-110.

Blackmore, J., Clark, L., The disposal of sheep dip waste. National Rivers Authority R\&D Report, 111994.

Cavalier, T.C., Lavy, T.L., Mattice, J.D., Persistence of selected pesticides in groundwater samples. Ground Water, 29 1991. 225-231.

Chilton, P.J., Stuart, M.E., Gardner, S.J., Diffuse pollution from land-use practices. National Rivers Authority Project Record, 113/10 1993. 
Chilton, P.J., Stuart, M.E., Lawrence, A.R., Gooddy, D.C., Williams, R.J., Johnson, A.C., Assessing pesticide pollution of groundwater: current knowledge and future gaps. In: Sililo, O. et al. (eds) Groundwater: Past Achievements and Future Challenges, International Association of Hydrogeologists, XXX Congress, Capetown., 2000. 17-25 Balkema, Rotterdam.

Chilton, P.J., Stuart, M.E., Gooddy, D.C., Williams, R.J., Johnson, A.C., Haria, A.H., Transport and fate of pesticides in the Chalk aquifer of southern England. British Geological Survey Research Report 2002. RR/02/04.

Clark, L.J., Gomme, J., Hennings, S., Study of pesticides in waters from a Chalk catchment, Cambridgeshire. Pesticide Science, 32 1991. 15-33.

Clark, L.J., Turrell, J., Fielding, M., Oakes, D.B., Wilson, I., Taylor, L., Pesticides in major aquifers. National Rivers Authority R\&D Report, 171995.

Environment Agency Pesticides 2000: a Summary of Monitoring of the Aquatic Environment in England and Wales., 2001. Environment Agency, Bristol.

Foster, S.S.D., Bridge, L.R., Geake, A., Lawrence, A.R., Parker, J.M., The groundwater nitrate problem. British Geological Survey Hydrogeology Research Report, 86/2 1986.

Foster, S.S.D., Chilton, P.J., Stuart, M.E., Mechanisms of groundwater pollution by pesticides. Journal of the Institution of Water and Environmental Management, 5 1991. 186193.

Geake, A., Foster, S.S.D., Sequential isotope and solute profiling in the unsaturated zone of British Chalk. Hydrological Science Journal, 34 1989. 79-95.

Gooddy, D.C., Bloomfield, J.P., Chilton, P.J., Johnson, A.C., Williams, R.J., Assessing herbicide concentrations in the saturated and unsaturated zone of a Chalk aquifer in southern England. Ground Water, 39 2001. 262-271.

Haria, A.H., Hodnett, M.G., Johnson, A.C., Mechanisms of groundwater recharge and pesticide penetration to a chalk aquifer in southern England. Journal of Hydrology, 2752003. $122-137$.

Heron, G., Christensen, T.H., Degradation of the herbicide mecoprop in an aerobic aquifer determined by laboratory batch studies. Chemosphere, 24 1992. 547-557.

Hughes, C.D., Gardner, S.J., Coombs, P., Chilton, P.J., Microcosm experiments to study mecoprop degradation in the Chalk aquifer of Hampshire. In: Walker, A., Allen, R., Bailey, S.W. et al. (eds) Pesticide Movement to Water. British Crop Protection Council Monograph, 62 1995. 207-210.

Johnson, A.C., Hughes, C.D., Williams, R.J., Chilton, P.J., Potential for aerobic isoproturon degradation and sorption in the unsaturated and saturated zones of a chalk aquifer. Journal of Contaminant Hydrology, 30 1998. 281-297.

Johnson, A.C., White, C., Bhardwaj, C.L., Potential for isoproturon, atrazine and mecoprop to be degraded in a chalk aquifer system. Journal of Contaminant Hydrology, 44 2000. 1-18. 
Johnson, A.C., Besien, T.J., Bhardwaj, C.L., Dixon, A., Gooddy, D.C., Haria, A.H., White, C., Penetration of herbicides to groundwater in an unconfined chalk aquifer following normal soil applications. Journal of Contaminant Hydrology, 53 2001. 101-117.

Johnson, A.C., White, C., Lal Bhardwaj, C., Dixon, A., The ability of indigenous microorganisms to degrade isoproturon, atrazine and mecoprop within aerobic UK aquifer systems. Pest Management Science, 59 2003. 1291-1302.

Kinniburgh, D.G., Miles, D.L., Extraction and chemical analysis of interstitial water from soils and rocks. Environmental Science \& Technology, 17 1983. 362-368.

Kinniburgh, D.G., Gale, I.N., Gooddy, D.C., Denitrification in the unsaturated zones of the British Chalk and Sherwood Sandstone aquifers. British Geological Survey Technical Report, WD/99/2 1999.

Klint, M., Arvin, E., Jensen, B.K., Degradation of the pesticides mecoprop and atrazine in unpolluted sandy aquifers. Journal of Environmental Quality, 22 1993. 262-266.

Kolpin, D.W., Thurman, E.M., Goolsby, D.A., Occurrence of selected pesticides and their metabolites in near-surface aquifers of the mid-western United States. Environmental Science \& Technology, 30 1996. 335-340.

Kristensen, G.B., Sorensen, S.R., Aamand, J., Mineralisation of 2,4-D, mecoprop, isoproturon and terbuthylazine in a chalk aquifer. Pesticide Management Science, 57 2001. 531-536.

Lawrence, A.R., Foster, S.S.D., Denitrification in a limestone aquifer in relation to the security of low-nitrate groundwater supplies. Journal of the Institution of Water and Engineering Science, 40 1986. 159-172.

Lees, A., McVeigh, K., An Investigation of Pesticide Pollution in Drinking Water in England and Wales., 1988. Friends of the Earth, London.

Lehr, S., Glaessgen, W.E., Sandermann, H., Beese, F., Scheunert, I., Metabolism of isoproturon in soils originating from different agricultural management systems and in cultures of isolated soil bacteria. International Journal of Analytical Chemistry, 65 1996. 231243.

Leistra, M., Boesten, J.J.T.I., Pesticide contamination of groundwater in western Europe. Agriculture, Ecosystems and Environment, 26 1989. 369-389.

Lewis, M.A., Jones, H.K., Macdonald, D.M.J., Groundwater storage in British aquifers: Chalk. National Rivers Authority Project Report R\&D, 128/8/A 1993.

Ministry of Agriculture, Fisheries and Food Arable farm crops in England and Wales. Pesticide Usage Survey Report, 851991.

National Rivers Authority Pesticides in the Aquatic Environment. National Rivers Authority Water Quality Series, 261995.

Price, M., Low, R.G., McCann, C., Mechanisms of water storage and flow in the unsaturated zone of the Chalk aquifer. Journal of Hydrology, 233 2000. 54-71.

Spliid, N.H., Køppen, B., Occurrence of pesticides in Danish shallow groundwater. Chemosphere, 37 1998. 1307-1316. 
Sweeney, J., Hart, P.A., McConvey, P.J., Investigation and management of pesticide pollution in the Lincolnshire Limestone aquifer in Eastern England. In: Mather, J., Banks, D., Dumpleton, S. \& Fermor, M. (eds) Groundwater Contaminants and their Migration. Geological Society, London, Special Publications, 128 1998. 347-360.

UK Water Industry Research Implications of changing groundwater quality for water resources and the UK water industry. Phase 1 review and scoping study. UK Water Industry Research, Report Ref., 02/WR/09/03 2003.

Walker, A., Jurado-Exposito, M., Bending, G.D., Smith, V.R., Spatial variability in the degradation rate of isoproturon in soil. Environmental Pollution, 111 2001. 407-415.

Walls, D., Smith, P.G., Mansell, M.G., Pesticides in groundwater in Britain. International Journal of Environmental Health Research, 6 1996. 55-62.

Wellings, S.R.Recharge of the Upper Chalk at a site in Hampshire, England. 2: Solute movement. Journal of Hydrology, 69 1984. 275-285.

Worrall, F., Besien, T., The vulnerability of groundwater to pesticide contamination estimated directly from observations of presence or absence in wells. Journal of Hydrology 2005. in press.

Worrall, F., Kolpin, D.W., Aquifer vulnerability to pesticide pollution-combining soil, landuse and aquifer properties with molecular descriptors. Journal of Hydrology, 2392004. 191-204.

Worrall, F.A., Parker, A., Rae, J.E., Johnson, A.C., A study of suspended and colloidal matter in the leachate from lysimeters and its role in pesticide transport. Journal of Environmental Quality, 28 1999. 595-604. 